\title{
Technological Upgradationon Educational Reforms in India
}

\author{
Anupam Sharma
}

\begin{abstract}
The moment journey of life starts education starts from that day. The moment baby born tries to adapt to outside world from that moment itself learning starts, along with activities liking crying, expressing, smiling, recognizing mothers touch etc. and the process goes on through lifetime. John Dewey said: "Education is not preparation for life, education is life itself." Over the years India has emerged as one of the largest education systems. However, witnessing the changes and developments in and around the world are forcing and demanding the further changes in the existing educational practices and delivery system if education. In the $21^{\text {st }}$ century the government of India has recognized the true importance of imparting education to the children of country and brought some legislative changes.
\end{abstract}

Index Terms-education, learning, developments, government

\section{INTRODUCTION}

Globalization has brought numerous opportunities for India, which the South-Asian country could make best benefits due to their demographic and economic potential. In India more than half of its population is of working age, and according to forecasts, by 2020 one quarter of the world's labour force will be made up by Indians.[1]. In the 1830's the Britishers introduced modern school system into the country, as a result of which the close relationship between master and disciple ceased to exist, and the curriculum featured primarily natural sciences[2].

According to Article 45 of the Constitution of the Republic of India, education is compulsory for children aged between 6-14, however the government is struggling to implement and enforce the constructional rules in certain areas even at the end of the $20^{\text {th }}$ century. At the outset, administration of education was considered each state's home affair. Thus, Indian government had little influence over questions concerning education policies implementation. This situation only changed in 1976, when, after an amendment to the Constitution, education came under the national government's purview.

Revised Manuscript Received on July 22, 2019

Dr Anupam Sharma, Thapar institute of engineering and technology Patiala, Punjab
[3] In the 1980s many legislative acts were passed to enforce compulsory education regulations and to develop elementary education. In this spirit the program "National Policy concerning Education" was passed, a modified version of which is still treated as a priority project by the Modi-government. Women's participation in education was minimal at the beginning, but by 2001, with government support, more than $50 \%$ of all women could read and write, which can be seen as a formidable step forward in comparison to $15 \%$ in the 1960 s. [4]

2011 results show the literacy rate among aged 7-10 is $75 \%$. This led to the positive effect on economic development as well. $80 \%$ of elementary schools are state-financed and imparts free education till class ten. Accordingly, in 1994 a new program was started to merge elementary education, which had contributed to the development of elementary education among Indian government schools. The newest program that aims to provide integrated education for all is named as SarvaShiksaAbhidjan, which is currently running as one of the greatest and chief educational initiatives of the world.[5]

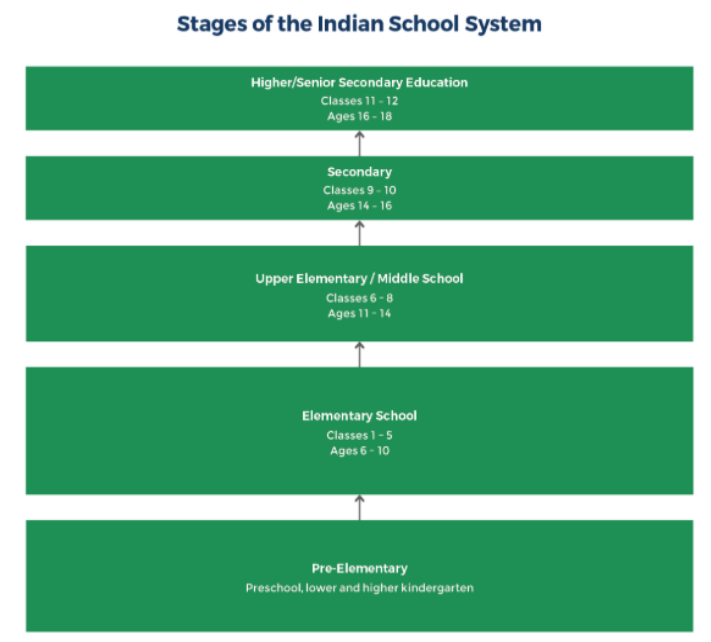

Figure 1: Source:wenr.wes.org

The table 1 given below address the philoshies behind imparting education system starting from British period to post independence and present scenario. 


\begin{tabular}{|c|c|c|}
\hline $\begin{array}{l}\text { ERA/ } \\
\text { PERIOD }\end{array}$ & PHILOSPHY & RESULT \\
\hline $\begin{array}{l}\text { BRITISH } \\
\text { PERIOD } \\
\text { 1) Anglicists } \\
\text { and } \\
\text { Orientalists }\end{array}$ & $\begin{array}{l}\text { The development of } \\
\text { education system } \\
\text { was determined by } \\
\text { the needs of colonial } \\
\text { powers. } \\
\text { Unofficial education } \\
\text { was brought to the } \\
\text { Indian masses } \\
\text { through the Charter } \\
\text { Act of } 1813 \text {. }\end{array}$ & $\begin{array}{l}\text { The Charter Act } \\
\text { created a } \\
\text { controversy between } \\
\text { the Anglicists and } \\
\text { the Orientalists. } \\
\text { There were no } \\
\text { specific regulations } \\
\text { made for } \\
\text { establishing the } \\
\text { schools and colleges } \\
\text { in India. }\end{array}$ \\
\hline $\begin{array}{l}\text { 2) } \\
\text { Macaulay } \\
\text { Minutes }\end{array}$ & $\begin{array}{l}\text { Lord Macaulay } \\
\text { wrote a minute on } \\
\text { the Feb 2, 1835, } \\
\text { where he made the } \\
\text { decision regarding } \\
\text { the controversy. } \\
\text { He laid stress on the } \\
\text { implementation of } \\
\text { English as the } \\
\text { medium of } \\
\text { instruction. } \\
\text { He was of the view } \\
\text { that might educate } \\
\text { the people in } \\
\text { capacity for better } \\
\text { governance. }\end{array}$ & $\begin{array}{l}\text { In his minute he } \\
\text { criticized the } \\
\text { oriental learning. } \\
\text { He wanted to spread } \\
\text { the western learning } \\
\text { across India. }\end{array}$ \\
\hline $\begin{array}{l}\text { 3)Woods } \\
\text { Education } \\
\text { Despatch of } \\
1854\end{array}$ & $\begin{array}{l}\text { East India company } \\
\text { had to review its } \\
\text { Charter after every } \\
\text { twenty years. } \\
\text { This had a properly } \\
\text { articulated system of } \\
\text { education, from } \\
\text { primary schools to } \\
\text { universities. }\end{array}$ & $\begin{array}{l}\text { This system was } \\
\text { known as the } \\
\text { MAGNA CARTA } \\
\text { of the modern } \\
\text { education. }\end{array}$ \\
\hline $\begin{array}{l}\text { 4)Hunter } \\
\text { Commission } \\
1882\end{array}$ & $\begin{array}{l}\text { Now the } \\
\text { responsibility of the } \\
\text { Indian education } \\
\text { system shifted from } \\
\text { the company to the } \\
\text { parliament. } \\
\text { Evaluation of } \\
\text { success of the } \\
\text { government schools } \\
\text { was an issue. }\end{array}$ & $\begin{array}{lr}\text { There } & \text { were } \\
\text { complaints that the } \\
\text { Woods Dispatch } \\
\text { was not followed } \\
\text { properly. }\end{array}$ \\
\hline
\end{tabular}

The following figure shows the comparative growth enrolment ratio for higher education along with difference in student teacher ratio across the world.

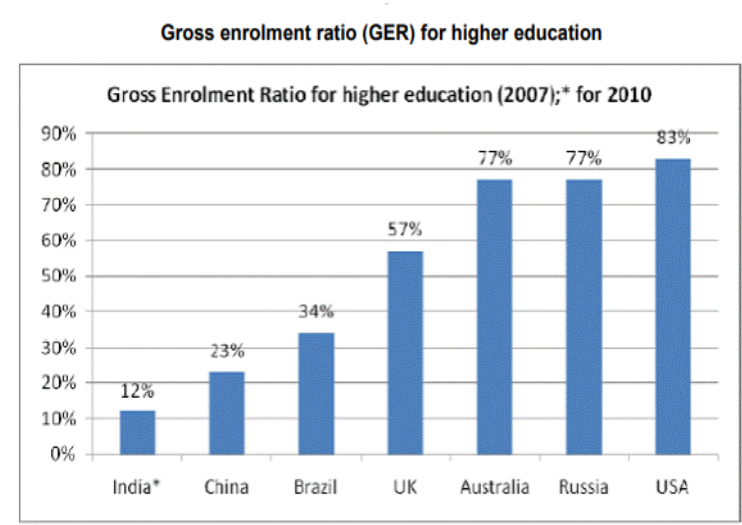

Source: chinaeducenter.com, UNESCO Global Education Digest 2009; EY Analysis

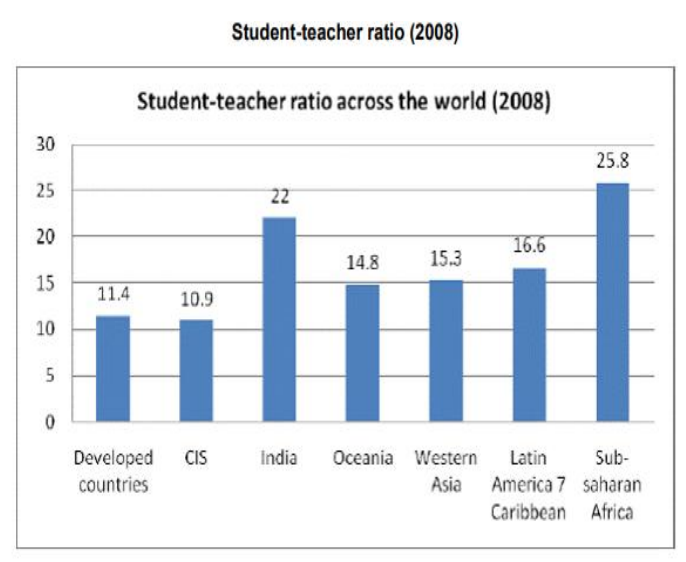

Source: "Higher Education in India", UGC Report, 2008; UNESCO Institute for Statistics 2010; EY Analysis

From the above that one can infer that results are quiet alarming with respect to Indian education system.

The diagram shows the transition in thoughts behind imparting education through religious opinions. It's evident from ancient studies that major focus behind imparting education at that time was culture and salvation. Major teaching were focused on making people aware about cultural changes so that people could differentiate between the truth and the illusion. Next is the Buddhist system that worked upon minimizing racial discrimination and resulted into the rise of organized public educational system. And anyone could take admission irrespective of their caste or religion. This had raised the education status to international level. And the next is Islamic education system focus was on creation of mankind. And Teachers laid emphasis on inculcation of moral and spiritual values. Educational institutions during that period were Maqtabs, Madrasa has and Mosques. 


\begin{tabular}{|c|c|c|}
\hline $\begin{array}{l}\text { 5)The University } \\
\text { Commission } \\
1902\end{array}$ & $\begin{array}{l}\text { Lord Curzon } \\
\text { pointed out that } \\
\text { no change had } \\
\text { been seen in } \\
\text { university } \\
\text { education } \\
\text { because they } \\
\text { didn't follow the } \\
\text { guidelines of the } \\
\text { London } \\
\text { university. }\end{array}$ & $\begin{array}{l}\text { The major defects } \\
\text { noticed were the } \\
\text { neglect ion of } \\
\text { professional } \\
\text { education and } \\
\text { technical } \\
\text { education } \\
\text { particular. in }\end{array}$ \\
\hline $\begin{array}{l}\text { 6)Development } \\
\text { of education } \\
\text { from 1921-1937 }\end{array}$ & $\begin{array}{l}\text { This period is } \\
\text { known for the } \\
\text { introduction of } \\
\text { Government of } \\
\text { India Acts } 1919 \\
\text { and 1935. } \\
\text { Laws } \\
\text { governed } \\
\text { universal primary } \\
\text { education were } \\
\text { passed. } \\
\text { An Auxiliary } \\
\text { committee } \\
\text { examined the } 102 \\
\text { defects } \\
\text { education } \\
\text { 1928. in }\end{array}$ & $\begin{array}{l}\text { This period drew } \\
\text { the attention } \\
\text { towards the } \\
\text { inefficiency of } \\
\text { the literary } \\
\text { education. } \\
\text { The inter } \\
\text { university board } \\
\text { was formed in } \\
1924 \text { May, in } \\
\text { Simla. it was } \\
\text { Then it } \\
\text { renamed as the } \\
\text { Association of } \\
\text { Indian } \\
\text { Universities. }\end{array}$ \\
\hline $\begin{array}{l}\text { 7)Other } \\
\text { Committees } \\
\text { The Sadler } \\
\text { commission, } \\
1917\end{array}$ & $\begin{array}{l}\text { This was also } \\
\text { known as the } \\
\text { Calcutta } \\
\text { University } \\
\text { Commission. } \\
\text { Post-graduation } \\
\text { knowledge was } \\
\text { also imparted in } \\
1916 \text { in the } \\
\text { university. }\end{array}$ & $\begin{array}{l}\text { Because of the } \\
\text { number } \\
\text { colleges } \\
\text { increasing in the } \\
\text { beyond control, } \\
\text { no other } \\
\text { universities were } \\
\text { opened for the } \\
\text { next thirty years. }\end{array}$ \\
\hline & $\begin{array}{l}\text { It was formed to } \\
\text { give its } \\
\text { suggestions on } \\
\text { the overall } \\
\text { improvement and } \\
\text { progress. }\end{array}$ & $\begin{array}{l}\text { The women, } \\
\text { Muslims and the } \\
\text { backward classes } \\
\text { had also } \\
\text { awakened and } \\
\text { there } \\
\text { progress in the } \\
\text { numbers. }\end{array}$ \\
\hline $\begin{array}{l}\text { The Wardha } \\
\text { Scheme of } \\
\text { Education } 1937\end{array}$ & $\begin{array}{l}\text { There was } \\
\text { considerable } \\
\text { progress in the } \\
\text { education system } \\
\text { in India in the } \\
\text { report by the } \\
\text { committee. }\end{array}$ & $\begin{array}{l}\text { The committee } \\
\text { was not satisfied } \\
\text { with the growth } \\
\text { of literacy in the } \\
\text { country. } \\
\text { It helped in the }\end{array}$ \\
\hline $\begin{array}{l}\text { Abbort Woods } \\
\text { Report } 1937\end{array}$ & $\begin{array}{l}\text { This is also } \\
\text { known as the } \\
\text { basic education. } \\
\text { The scheme was } \\
\text { the outcome of } \\
\text { sound thinking of }\end{array}$ & $\begin{array}{l}\text { economic, } \\
\text { educational and } \\
\text { the social } \\
\text { development of } \\
\text { the people. }\end{array}$ \\
\hline Education & $\begin{array}{l}\text { Gandhi's. } \\
\mathrm{He} \text { considered }\end{array}$ & $\begin{array}{lr}\text { No } & \text { special } \\
\text { schools } & \text { for }\end{array}$ \\
\hline
\end{tabular}

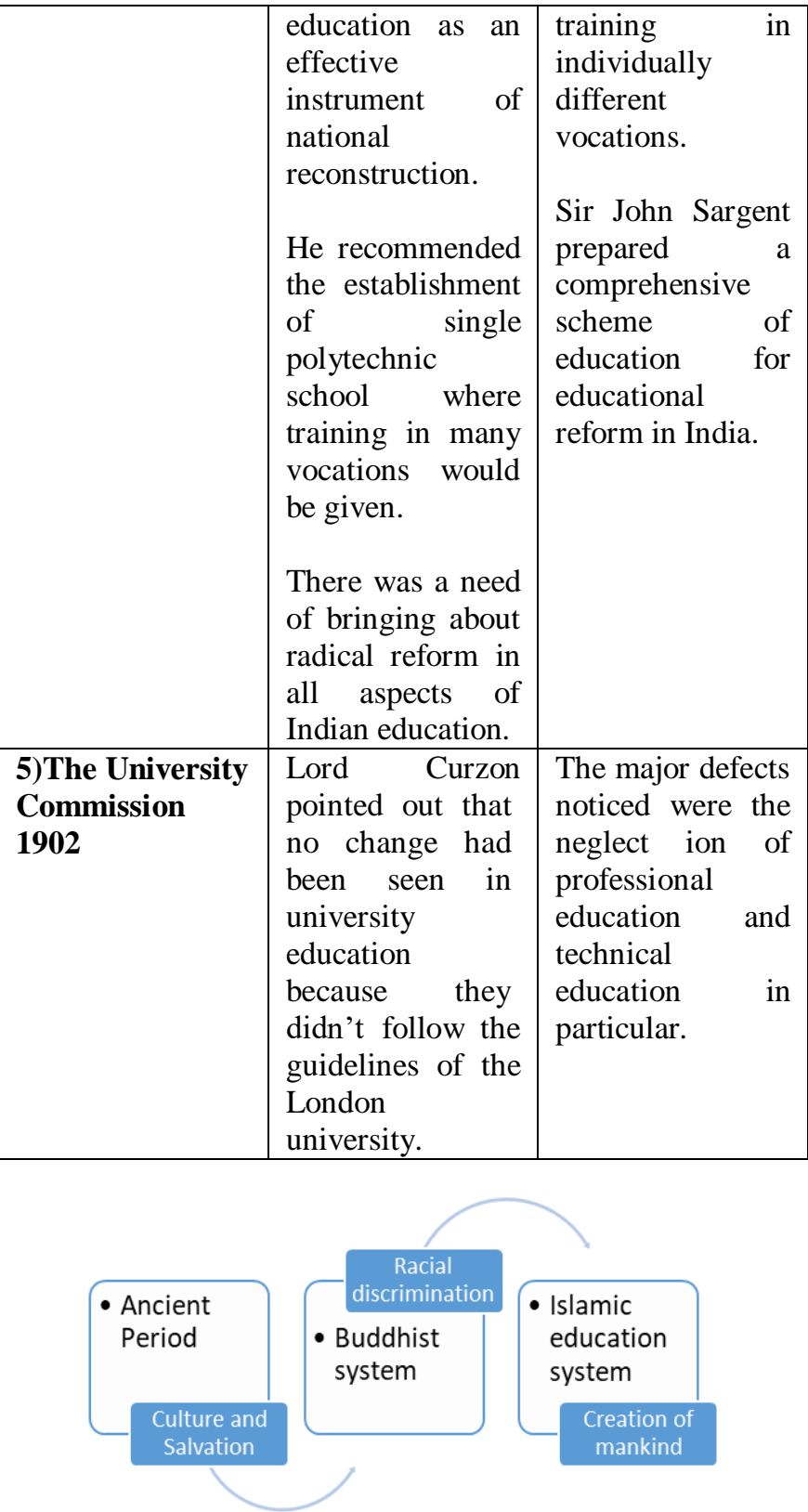

Figure 4: Religion based educational activities

The importance of education can be seen in development of nation, social change and social mobility are one of the vital components in each developmental effort in a contemporary society. The National Policy on Education (1986) agreed with the vision that education is important for shaping the future of the any society and indicated it as the backbone of all national activities particularly in societies, which have preferred a autonomous path of development.

\section{THE SARVA SHIKSHA ABHIYAN (SSA)}

The following table shows the growth and progress overview by the initiation of SARVA SHIKSHA ABHIYAN. The aim of this flagship program was to accomplish universalization of primary schooling at a satisfactory level by 2010. SSA is being applied in conglomerate with State Governments to cover the whole country and address 
the requirements of 192 million children in 1.2 million residences. The present rules of SSA have been changed recently by pushing into practice the "Right of Children to free and Compulsory Education" which is compulsory to implement from April 1, 2010 onwards.

\begin{tabular}{|c|c|}
\hline Access & $\begin{array}{l}99 \% \text { of the rural population has a primary school within } 1 \mathrm{~km} .366559 \text { new } \\
\text { schools opened till September, } 2010 \text {. }\end{array}$ \\
\hline $\begin{array}{l}\text { Gross } \\
\text { Enrolment } \\
\text { Ratio }\end{array}$ & $\begin{array}{l}\text { GER increased in 6-14 age groups to } 114.37 \text { in } 2008-09 \text { from } 96.3 \text { in 2001-02 } \\
\text { at the primary level and to } 76.23 \text { in } 2008-09 \text { from } 60.2 \text { in } 2001-02 \text { at the } \\
\text { upper primary level. }\end{array}$ \\
\hline $\begin{array}{l}\text { Gender Parity } \\
\text { Index (GPI) }\end{array}$ & $\begin{array}{l}\text { Improved from } 0.83 \text { in } 2001-02 \text { to } 1.00 \text { in } 2008-09 \text { at primary level \&from } \\
0.77 \text { to } 0.96 \text { at upper primary level. }\end{array}$ \\
\hline $\begin{array}{l}\text { Dropout Rate } \\
\text { at the primary } \\
\text { level }\end{array}$ & $\begin{array}{l}\text { Reduced by } 14.10 \% \text { to } 24.93 \% \text { in } 2008-09 \text { from } 39.03 \% \text { in } 2001-02 \text {. Dropout } \\
\text { rate for girls declined by } 16.98 \% \text { points during same period. }\end{array}$ \\
\hline $\begin{array}{l}\text { Pupil-Teacher } \\
\text { Ratio }\end{array}$ & $\begin{array}{l}\text { In 2008-09 the PTR at the national level was } 44: 1 \text { for primary and } 34: 1 \text { for } \\
\text { upper primary level. } 11.13 \text { lakh teachers recruited by December, } 2010 \text {. }\end{array}$ \\
\hline
\end{tabular}

As for the year 2011-2012, under SSA budget the Union budget ministry have laid apportion an amount of Rs 21,000 crore, which is nearly $40 \%$ higher than the last year budget for SSA.

\section{SUGGESTIONS}

(a) India has to expand on all aspects which have effect on value of higher education system. This can be done by setting committees or framing organizations so that they can keep track of activities and improve on considerable factors. Thus, the submissions of these committees and organizations must be implemented.

(b) India has to take healthier steps to develop gross enrolment ratio by growing public spending on education.

(c) Government can also make efforts toward providing free or affordable education to all till graduation.

(d) Government must take steps to develop the number of inbound mobile pupils by increasing the public expenditure on programs or participation in global fairs.

\section{CONCLUSION}

We can conclude that all the positive relevant steps have been taken to cater the changes demanded in the education sector. However, implementation of these initiatives will be defining the key to success. Paper has discussed the timely reforms incorporated since Britishers era and teachings based upon different religious norms and we can say that the path covered wasn't that easy. Construction of walls, windows, doors and teachers are not sufficient to make a school, in India we have starving children working in the fields and factories, to earn their meals.

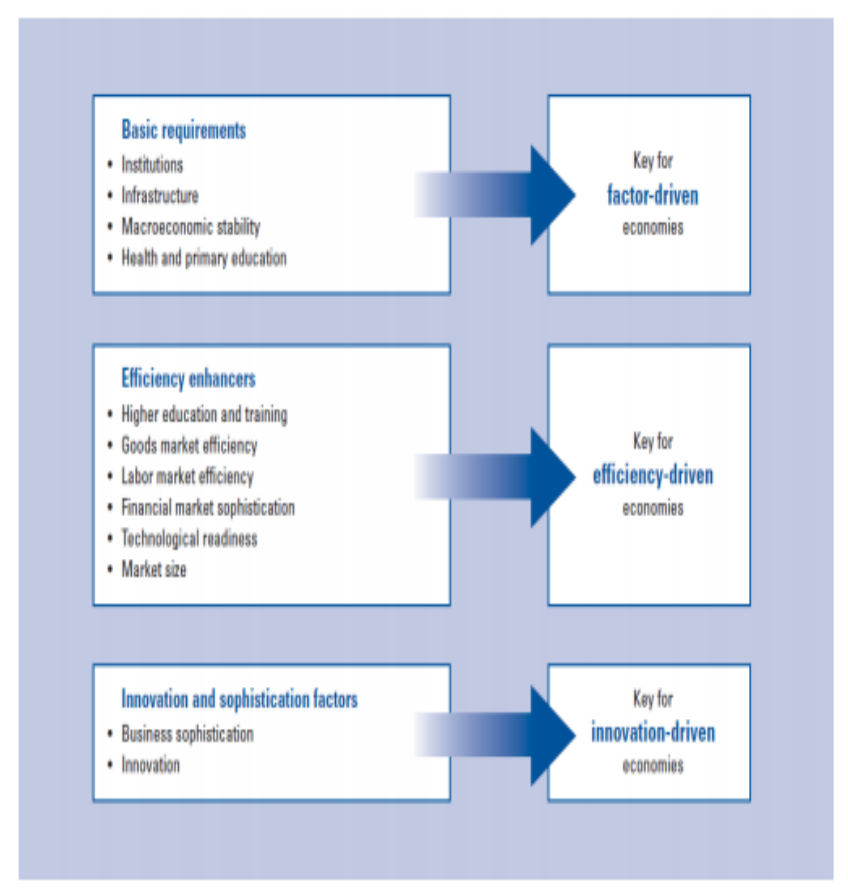

Figure 5: Pillars of effectiveness

The Vision and Mission of Education for all by SarvaShikshaAbhiyan will have to be inculcated and imbibe in one and all, including leaders, policy makers and followers that for every child born deprived and poor, there will be having a well-drawn plan, that make ensure that s/he doesn't remain so, for if we fail in providing the basic psychological needs of food and shelter and clothing to a child, she/he will never be able to see the light of the bright day, through education so it's not only the duty of Government to frame the policies but as a independent citizen of nation its duty of every one of us to ensure that the every child should be benefited by the basic human right of one education for all.

\section{REFERENCE}

1. VERNAL, Louis: Drive reforms in education system. In: The Times of India, August 7, 2014 http://timesofindia.indiatimes.com/home/education/news/Drivereforms-in-education-system/articleshow/39779780.cms (2016.04.25).

2. KUMAR, Sasi V.: The Education System in India. GNU Operating System http://www.gnu.org/education/edusystem-india.html (2016.04.19)

3. RAMAN, S. A.: Woman's Education. in: Stanley, Wolpert (edit): Encyclopedia of India, Vol 4. Thomson Gale, 2006. 236.

4. National Council of Educational Research and Training: Leading the Change. New Delhi, 2011. http://www.ncert.nic.in/oth anoun/leading the change.pdf (2016.04.25)

5. SarvaShikshaAbhiyan. Ministry of Human Resource Development. http://ssa.nic.in/ (2016.04.25).

6.Annual Reports, 2010-11, (2011) Department of School Education \& Literacy and Department of Higher. 